\title{
Analisis Pengaruh Tingkat Pemahaman Pajak Kos Terhadap Kepatuhan Wajib Pajak \\ (Studi kasus pada pemilik usaha kos di Kecamatan Umbulharjo Kota Yogyakarta)
}

\author{
Dwi Priyanto ${ }^{1)}$ \\ dpriyanto1991@gmail.com \\ Eliya Isfaatun ${ }^{1)}$ \\ isfaatuneliya@gmail.com \\ Akuntansi STIE Nusa Megarkencana
}

\begin{abstract}
Tax revenue is important in increasing tax revenue in Yogyakarta. Taxrates for boarding houses with more than 10 (ten) rooms are set at 5\% (five percent). Increase tax revenue which is supported by an understanding of the tax owned by the boarding house owner, so that he complies with taxation. This research is intended to study the level of understanding of taxes for taxpayer assistance.

This type of research is quantitative research. The population in this study is the owner of a tax business in Yogyakarta's Umbulharjo District which holds 710 people. The sampling technique used is the Slovin technique, which is a boarding business owner in the Umbulharjo District of Yogyakarta City which holds 256 people. The instrument used was a questionnaire. Data analysis techniques using the validity and reliability test, normality test, linearity test, simple regression analysis, $t$ test, and the coefficient of determination test.
\end{abstract}

The results showed there were significant and significant differences in the level of tax understanding of tax liabilities. This is evidenced through the t test with the results of $t$ count $15.920>t$ table 1.650 and the regression equation $Y=$ $14.516+0.671 X$. From these results it means that the higher the cost of income tax, the higher the taxpayer approval. This is also supported by a significance value of 0,000, which means this significance value is less than 0.05.

Key Words: understanding boarding tax, tax obligations, boarding businesses in Umbulharjo District

\section{PENDAHULUAN}

Penerimaan negara sangat penting bagi pelaksanaan dan pembangunan nasional yang bertujuan untuk meningkatkan kemakmuran dan kesejahteraan masyarakat. Di Indonesia salah satu penerimaan negara terbesar adalah berasal dari pajak. Penerimaan 


\section{Dwi Priyanto, Eliya Isfaatun}

pajak terdiri dari penerimaan pajak pusat dan pajak daerah. Pengenaan pajak terhadap rumah kos menjadi berita yang banyak diperbincangkan dalam masyarakat. Secara yuridis, pajak kos-kosan diatur dalam pajak hotel yang termasuk dalam pajak daerah. Pajak kos-kosan dikenakan terhadap objek pajak yang merupakan rumah kos yang memiliki kamar sekurang-kurangnya sepuluh buah (sepuluh pintu). Dinas Pendapatan Daerah Kota Yogyakarta mengadakan sosialisasi ke beberapa Kecamatan yang dinilai potensial oleh Pemerintah Daerah. Sosialisasi tersebut dilaksanakan di tingkat kelurahan dengan cara bekerjasama dengan menghadirkan para tokoh masyarakat, RT, RW dan pemilik rumah kos yang memenuhi kriteria sebagai wajib pajak.

Kota Yogyakarta sebagai salah satu daerah di Daerah Istimewa Yogyakarta yang menjalankan otonomi Daerah, berusaha untuk mewujudkan tujuan tersebut. Salah satu usaha yang dilakukan adalah dengan melakukan pengaturan penduduk khususnya bagi pendatang yang berdiam sementara dengan tujuan menuntut ilmu/pendidikan dan atau mencari nafkah/pekerjaan, mengingat Kota Yogyakarta merupakan daerah yang mempunyai potensi mobilitas penduduk yang cukup tinggi. Dengan adanya mobilitas penduduk ini tentu saja sangat berpengaruh terhadap perkembangan dan kepadatan penduduk. Disamping itu dengan adanya keanekaragaman sosial budaya serta interaksi sosial antar kultur, perlu didukung dengan administrasi kependudukan yang memadai sehingga permasalahan-permasalahan kependudukan yang timbul dapat diselesaikan dengan sebaik-baiknya.

Keberadaan pemondokan di Kota Yogyakarta dapat berpengaruh terhadap nilainilai sosial dan budaya masyarakat setempat serta tertib administrasi kependudukan dan untuk memelihara nilai-nilai sosial dan budaya masyarakat, mewujudkan ketertiban umum, tertib administrasi kependudukan, dan kelestarian lingkungan maka perlu adanya pengaturan pondokan. Berdasarkan pertimbangan tersebut, dibentuklah Peraturan Daerah Kota Yogyakarta Nomor 4 Tahun 2003 Tentang Penyelenggaraan Pondokan. Dalam Pasal 1 huruf d Peraturan Daerah tersebut yang dimaksud pondokan adalah rumah atau kamar yang disediakan untuk tempat tinggal dalam jangka waktu tertentu bagi seseorang atau beberapa orang dengan dipungut atau tidak dipungut bayaran. Di Kecamatan Umbulharjo terdapat beberapa Universitas seperti: UAD, UST, UTY, STIE Widya Wiwaha, Universitas Janabadra, Universitas Cokro Aminoto, STPMD APMD, APY, Stikes Yogyakarta, dan Akademi Farmasi Yogyakarta. Dengan keberadaan universitas tersebut maka merebak usaha sewa kamar atau disebut juga sebagai rumah kos di sekitar kampus. Ini terjadi karena para pelajar yang kebanyakan berasal dari luar kota membutuhkan tempat tinggal sementara waktu bagi mereka yang menuntut ilmu. Melihat dari semakin tingginya kebutuhan tempat tinggal (kos-kosan), maka semakin banyak masyarakat yang melihat usaha kos- kosan sebagai peluang bisnis.

Dengan potensi kos yang dimiliki Kecamatan Umbulharjo, maka kebijakan Pajak Kos diatur melalui Peraturan Daerah Kota Yogyakarta No 1 tahun 2011 tentang Pajak Hotel. Di dalam Perda tersebut dinyatakan bahwa "Hotel adalah fasilitas penyedia jasa penginapan/peristirahatan termasuk jasa terkait lainnya dengan dipungut bayaran, 
yang mencakup juga motel, losmen, gubuk pariwisata, wisma pariwisata, pesanggrahan, rumah penginapan dan sejenisnya, serta rumah kos dengan jumlah kamar lebih dari 10 (sepuluh)". Berdasarkan hasil survei di Kecamatan Umbulharjo tercatat hanya 12 wajib pajak dari 710 orang yang patuh melaporkan pajak kos. Hal tersebut menjadi dasar peneliti untuk melakukan penelitian ini.

Penyelenggaraan Pondokan dilaksanakan berdasarkan asas kekeluargaan dengan berpedoman pada norma-norma hukum, agama, adat dan kepatutan. Pasal 4 Peraturan Daerah Kota Yogyakarta Nomor 4 tahun 2003 tentang Penyelenggaraan Pondokan menyebutkan bahwa tujuan pengaturan penyelenggaraan pondokan adalah:

1. Mewujudkan Kota Yogyakarta BERHATI NYAMAN;

2. Melestarikan dan mengembangkan Yogyakarta sebagai kota pendidikan dan budaya;

3. Penataan dan pengendalian kependudukan;

4. Menjaga ketenteraman dan ketertiban dalam kehidupan bermasyarakat.

Setiap orang yang memiliki pondokan berupa rumah atau kamar lebih dari 2 (dua) kamar atau dihuni lebih dari 5 (lima) orang pemondok wajib memiliki Izin Penyelenggaraan Pondokan. Izin Penyelenggaraan Pondokan diberikan oleh Walikota atau pejabat yang ditunjuk. Syarat-syarat untuk memperoleh Izin Penyelenggaraan Pondokan adalah sebagai berikut: (1) Membuat surat pernyataan sanggup untuk memenuhi kewajiban-kewajiban, (2) Memiliki Izin Mendirikan Bangun-Bangunan (IMBB); (3) Memiliki Izin Gangguan (HO).

Usaha kos adalah usaha yang mampu memberikan passive income yang bersifat rutin bagi pemiliknya. Pembayaran sewa kost oleh penghuni dilakukan setiap bulan. Usaha kost-kostan dinilai menguntungkan karena dapat membuka peluang usaha baru dan memperoleh penghasilan tambahan dengan membuka jasa loundry, katering, atau toko kelontong. Kepatuhan bukan merupakan tindakan yang mudah untuk direalisasikan oleh setiap wajib pajak. Kebanyakan dari masyarakat memiliki kecenderungan untuk dapat meloloskan diri dari kewajibannya membayar pajak dan melakukan tindakan melawan pajak.

Sebagaimana penelitian terdahulu yang dilakukan oleh Tarjo \& Indra Kusumawati (2016) menyimpulkan bahwa pelaksanaan self assement system belum biasa diterapkan oleh wajib pajak orang pribadi terutama pemilik usaha kos-kosan karena mereka sering kali tidak melaporkaan atau mencantumkan pajak penghasilan di SPT. Penelitian Wandayu \& Pusposari (2016) juga menemukan bahwa para pemilik kos tidak paham dengan peraturan pajak penghasilan atas persewaan tanah dan bangunan. Oleh karena itu, peneliti tertarik untuk mengangkat isu mengenai pemahaman pemilik usaha kos tentang peraturan pajak kos.

Dari hasil penelitian yang dilakukan oleh Prawagis (2016) menyimpulkan bahwa pelaksanaan self assement system belum biasa diterapkan oleh wajib pajak orang pribadi terutama pemilik usaha kos-kosan karena mereka sering kali tidak melaporkan pajak penghasilan. Hasil penelitian Ananda (2015) menemukan bahwa para pemilik kos 


\section{Dwi Priyanto, Eliya Isfaatun}

tidak paham dengan peraturan pajak penghasilan atas persewaan tanah dan bangunan.

Berdasarkan latar belakang di atas, judul yang dapat diangkat dalam penelitian ini adalah "Pengaruh Tingkat Pemahaman Pajak Kos terhadap Kepatuhan Wajib Pajak" (Studi kasus pada pemilik usaha kos di Kecamatan Umbulharjo Kota Yogyakarta).

\section{KAJIAN LITERATUR DAN TEORI}

\section{Kajian tentang Pajak}

Menurut Wirawan \& Bulton (2013: 6), pajak adalah iuran wajib berupa uang atau barang, yang dipungut oleh penguasa berdasarkan norma-norma hukum, guna menutup biaya produksi barang-barang dan jasa-jasa kolektif dalam mencapai kesejahteraan umum. Sebagai roh yang memberi kehidupan bagi kelangsungan suatu negara, tentunya sektor pajak perlu mendapat perhatian yang istimewa dari pemerintah sebagai penyelenggara negara. Slamet dan Jurdy (2015) menyatakan: "Pajak telah berfungsi sebagai sumber dana bagi pemerintah untuk membiayai pengeluaran- pengeluarannya. Salah satu pem- biayaan negara yang penting dalam hal ini adalah pembangunan sosial kemanusiaan, selain pembiayaan lainnya. Dalam teori negara bahwa negara melakukan fungsinya untuk melayani kebutuhan masyarakat, tidak untuk kepentingan pribadi." Artinya pajak merupakan salah satu cara untuk membiayai seluruh pembangunan di Negara Indonesia yang digunakan untuk kesejahteraan masyarakat.

\section{Pajak Daerah}

Pajak Daerah diatur dalam Undang-Undang Nomor 18 Tahun 1997 tentang Pajak Daerah dan Retribusi Daerah sebagaimana telah diubah dengan Undang- Undang Nomor 34 Tahun 2000 dengan perubahan terakhir yaitu Undang-Undang Nomor 28 Tahun 2009 tentang Pajak Daerah dan Retribusi Daerah,yang mana merupakan sumber pendapatan daerah yang digunakan untuk membiayai peaksanaan pemerintahan daerah. Peraturan daerah ini merupakan peraturan perundang-undangan yangdibentuk oleh DPRD provinsi dan/atau daerah kabupaten/kota dengan persetujuan bersama Kepala Daerah.

UU N0. 28 Tahun 2009 tentang PDRD, sebagai pengganti dari UU N0. 18 Tahun 1997 sebagaimana telah diubah dengan UU No. 34 Tahun 2000 juga lebih mempertegas pengertian pajak dalam tataran pemerintahan yang lebih rendah (daerah), sebagai berikut: "Pajak daerah adalah kontribusi wajib kepada daerah yang terutang oleh orang pribadi atau badan yang bersifat memaksa berdasarkan undang-undang, dengan tidak mendapatkan imbalan secara langsung dan digunakan untuk keperluan Daerah bagi sebesar-besarnya kemakmuran rakyat."

\section{Kepatuhan Wajib Pajak}

Kepatuhan wajib pajak merupakan pemenuhan kewajiban perpajakan yang dilakukan oleh wajib pajak dalam rangka pemberian kontribusi bagi pembangunan 
Negara yang diharapkan dalam pemenuhannya dilakukan secara sukarela. Muliari dan Setiawan (2011) mendefinisikan kepatuhan wajib pajak sebagai suatu keadaan dimana wajib pajak memenuhi semua kewajiban perpajakan dan melaksanakan hak perpajakannya. Kesadaran membayar pajak dapat diartikan sebagai suatu bentuk sikap moral yang memberikan sebuah kontribusi kepada negara untuk menunjang pembangunan negara dan berusaha untuk mentaati semua peraturan yang telah ditetapkan oleh negara serta dapat dipaksakan kepada wajib pajak (Nugroho \& Zulaikha, 2012)

Berdasarkan Keputusan Menteri Keuangan Nomor 235/KMK. 03/2003 Tanggal 3 Juni 2003 wajib pajak dikatakan patuh apabila:

a. Tepat waktu dalam menyampaikan Surat Pemberitahuan Tahunan dalam 2 (dua) tahun terakhir.

b. Dalam tahun terakhir penyampaian SPT Masa yang terlambat tidak lebih dari 3 (tiga) masa pajak untuk setiap jenis pajak dan tidak berturut-turut.

c. SPT Masa yang terlambat sebagaimana dimaksud dalam hurufb telah disampaikan tidak lewat dari batas waktu penyampaian SPT Masa pajak berikutnya.

d. Tidak mempunyai tunggakan pajak yang semua jenis pajak:

1) Kecuali telah memperoleh izin untuk mengangsur atau menunda pembayaran pajak.

2) Tidak termasuk tunggakan pajak sehubungan dengan STP yang diterbitkan untuk 2 (dua) masa pajak terakhir.

e. Tidak pernah dijatuhi hukuman karena melakukan tindak pidana di bidang perpajakan dalam jangka waktu 10 (sepuluh) tahun terakhir.

f. Dalam hal laporan keuangan diaudit oleh Akuntan Publik atau Badan Pengawas Keuangan dan Pembangunan harus dengan pendapat wajar tanpa pengecualian atau dengan pendapat wajar dengan pengecualian sepanjang pengecualian tersebut tidak mempengaruhi laba rugi fiskal. Laporan audit harus:

1) Disusun dalam bentuk panjang (long form report).

2) Menyajikan rekonsiliasi laba rugi komersil dan fiskal.

\section{Pemahaman Pemilik Kos}

Purwanto (2013: 44), menyatakan pemahaman atau komprehensi adalah tingkat kemampuan seseorang yang diharapkan mampu memahami arti atau konsep, situasi, serta fakta yang diketahuinya, sehingga seseorang tidak hanya hafal secara verbalistis tetapi juga memahami konsep dari masalah atau fakta yang ditanyakan. Memahami dengan kata lain adalah mengerti tentang sesuatu dan dapat melihatnya dari berbagai segi. Menurut Rahayu (2010: 141) terdapat beberapa indikator wajib pajak dalam mengetahui dan memahami peraturan perpajakan, yaitu:

Pengetahuan mengenai ketentuan umum dan tata cara perpajakan Ketentuan Umum dan Tata Cara Perpajakan sudah diatur dalam Undang-Undang Republik 


\section{Dwi Priyanto, Eliya Isfaatun}

Indonesia Nomor 6 tahun 1983 yang kemudian mengalami beberapa perubahan atau penyempurnaan yang menghasilkan Undang-Undang Nomor 16 tahun 2009 tentang Penetapan Peraturan Pemerintah Pengganti Undang-Undang Nomor 5 Tahun 2008 Tentang Perubahan Keempat Atas Undang- Undang Nomor 6 Tahun 1983 Tentang Ketentuan Umum dan Tata Cara Perpajakan Menjadi Undang-Undang. Perlu diadakan pembaharuan sistem perpajakan yang berlaku dengan sistem yang memberikan kepercayaan kepada subjek pajak untuk melaksanakan kewajiban serta memenuhi haknya di bidang perpajakan, sehingga dapat mewujudkan perluasan dan peningkatan kesadaran kewajiban perpajakan serta meratakan pendapatan masyarakat. Isi dari ketentuan umum dan tata cara perpajakan

Pengetahuan mengenai ketentuan umum dan tata cara perpajakan Ketentuan Umum dan Tata Cara Perpajakan sudah diatur dalam Undang-Undang Republik Indonesia Nomor 6 tahun 1983 yang kemudian mengalami beberapa perubahan atau penyempurnaan yang menghasilkan Undang-Undang Nomor 16 tahun 2009 tentang Penetapan Peraturan Pemerintah Pengganti Undang-Undang Nomor 5 Tahun 2008 Tentang Perubahan Keempat Atas Undang- Undang Nomor 6 Tahun 1983 Tentang Ketentuan Umum dan Tata Cara Perpajakan Menjadi Undang-Undang. Perlu diadakan pembaharuan sistem perpajakan yang berlaku dengan sistem yang memberikan kepercayaan kepada subjek pajak untuk melaksanakan kewajiban serta memenuhi haknya di bidang perpajakan, sehingga dapat mewujudkan perluasan dan peningkatan kesadaran kewajiban perpajakan serta meratakan pendapatan masyarakat. Isi dari ketentuan umum dan tata cara perpajakan

\section{Pengertian Usaha Kos}

Berdasarkan kamus besar bahasa Indonesia, kos atau indekos adalah menumpang tinggal di kamar atau rumah yang disewakan. Dengan demikian pengertian usaha kos adalah suatu bentuk kegiatan usaha dimana kejadian ekonomi yang terjadi adalah proses menyewakan bagian rumah tinggal (kamar) atau bangunan yang sengaja dibuat untuk disewakan kepada orang lain dengan jangka waktu tertentu.

Kos secara sederhana didefinisikan sebagai menempati satu ruang (kamar) rumah seseorang, dengan perjanjian membayar dalam jumlah tertentu sebagai kompensasi sewa dan fasilitas lain di dalamnya, seperti makan dan perabot yang dipakai. Kos-kosan merupakan tempat yang disediakan untuk memfasilitasi wanita maupun pria, dari pelajar, mahasiswa, dan pekerja umumnya untuk tinggal, dan dengan proses pembayaran per bulan, atau sesuai pemilik (ada yang per beberapa bulan, per tahun). Fungsi koskosan ini sebagai tempat tinggal, saat ini berkembang dnegan penambahan aktifitas dan sarana pendukung baik di dalam lokasi bangunan (kos-kosan) maupun di sekitar kosan tersebut. Misalnya ada kos-kosan yang menyediakan failitas warnet di bagian depan kos-kosan, yang dibuka seharian maupun beberapa jam untuk umum, kemudian fasilitas rumah makan, failitas kesehatan, dan sebagainya. 
Menurut Kamus Besar Bahasa Indonesia kata yang tepat adalah KOS/kos-kosan, sedangkan dalam Bahasa Inggris "cost" berarti harga atau pembayaran. Ada beberapa definisi yang perlu kita ketahui:

a. in-de-kos adalah tinggal di rumah orang lain dengan atau tanpa makan (dengan membayar setiap bulan); memondok;

b. meng-in-de-kos-kan adalah menumpangkan seseorang tinggal dan makan dengan membayar; memondokkan.

Dari kedua definisi di atas, dapat disimpulkan bahwa pemilik rumah indekos adalah orang pribadi atau badan yang memiliki rumah, kamar, atau bangunan, yang disewakan kepada pihak lain sebagai tempat tinggal/pemondokan dan mengenakan pembayaran sebagai imbalan dalam jumlah tertentu.

\section{Kerangka Pemikiran}

Banyaknya rumah kos yang didirikan di sekitar kawasan tersebut. Hal ini tentu membawa permasalahan tersendiri pada tempat tinggal yang diperlukan. Banyaknya pengusaha maupun penduduk asli di Yogyakarta memanfaatkan situasi ini sebagai sebuah peluang usaha rumah kos, rumah kontrakan, penginapan atau hotel. Rumah kos di Kota Yogyakarta menjadi tempat hunian yang paling diminati untuk warga pendatang yang bekerja dan belajar di kota ini. Terkadang para pemilik kos-kosan menutupnutupi kebenaran misalnya dengan mengatakan bahwa jumlah kamar yang digunakan kurang dari sepuluh. Pihak dari Pemerintah yang menangani kos-kosan mengalami kesulitan untuk mendatangi pemiliknya. Hal tersebut dikarenakan pemiliknya susah untuk ditemui. Pemahaman wajib pajak adalah pemahaman wajib pajak terhadap sistem pemungutan pajak yang ada di Indonesia dan segala macam peraturan peraturan perpajakan yang berlaku (I Gede Putu Pranadata, 2014). Sistem pemungutan pajak di Indonesia adalah sistem self assessment. Dalam sistem pemungutan pajak seperti ini tentunya diperlukan macam-macam peraturan yang digunakan sebagai alat kontrol dan pemahaman wajib pajak sehingga berpengaruh terhadap sukses atau tidaknya penerapan sistem pemungutan self assessment ini. Adanya ketidakpahaman wajib pajak terhadap peraturan pajak cenderung menjadi wajib pajak yang tidak patuh. Hal ini yang menjadi dasar adanya dugaan bahwa pemahaman wajib pajak tentang peraturan perpajakan berpengaruh terhadap kepatuhan wajib pajak. Berdasarkan kerangka pemikiran di atas, maka dapat dirumuskan hipotesis dalam penelitian ini yaitu "Ada pengaruh tingkat pemahaman pajak kos terhadap kepatuhan wajib pajak".

\section{METODE PENELITIAN}

\section{Jenis Penelitian}

Jenis penelitian ini merupakan penelitian deskriptif kuantitatif. Menurut Sugiyono (2013) deskriptif kuantitatif yaitu metode penelitian yang berlandaskan pada filsafat 


\section{Dwi Priyanto, Eliya Isfaatun}

positivisme, digunakan untuk meneliti pada populasi atau sampel tertentu, pengumpulan data menggunakan instrumen penelitian, analisis data bersifat kuantitatif/statistik, dengan tujuan untuk menguji hipotesis yang telah ditetapkan.

\section{Populasi dan Sampel Penelitian}

Populasi dalam penelitian ini adalah responden yang merupakan pemilik usaha pajak kos di Kecamatan Umbulharjo Kota Yogyakarta yang berjumlah 710 orang pemilik kos dari masing-masing RW. Teknik sampling yang digunakan yaitu teknik Slovin. Berdasarkan rumus di atas, didapatkan jumlah sampel sebesar 256. Jadi sampel dalam penelitian ini adalah pemilik usaha kos di Kecamatan Umbulharjo Kota Yogyakarta yang berjumlah 256 orang.

\section{Instrumen Penelitian dan Teknik Pengumpulan Data}

Instrumen pengumpulan data yang digunakan di lapangan berupa kuesioner. Menurut Sugiyono (2013: 142), "Koesioner merupakan teknik pengumpulan data yang dilakukan dengan cara memberi seperangkat pertanyaan atau peryataan tertulis kepada responden untuk dijawabnya." Kisi-kisi instrumen disajikan pada Tabel 3.1 sebagai berikut:

Tabel 1. Kisi-Kisi Instrumen Penelitian

\begin{tabular}{|c|c|c|c|}
\hline No & Variabel & Faktor & No Butir \\
\hline \multirow[t]{13}{*}{1} & \multirow{13}{*}{$\begin{array}{l}\text { Kepatuhan Wajib Pajak } \\
\text { (Y) } \\
\text { (Bryan Wahyu } \\
\text { Rahmanto, 2015) }\end{array}$} & \begin{tabular}{|l} 
Jenis Pajak \\
\end{tabular} & 1 \\
\hline & & Pendaftaran & 2 , \\
\hline & & Sistem Pemungutan Pajak & 3 \\
\hline & & Dasar Pengenaan Pajak & 4 \\
\hline & & \begin{tabular}{|l|} 
Tarif Pajak \\
\end{tabular} & 5 \\
\hline & & Cara Menghitung & 6 \\
\hline & & Cara Pemungutan & 7 \\
\hline & & Masa Pajak & 8 \\
\hline & & Cara Pembayaran & 9,10 \\
\hline & & Hak Wajib Pajak & 11 \\
\hline & & Banding Wajib Pajak & 12,13 \\
\hline & & Sanksi Wajib Pajak & 14 \\
\hline & & Fungsi Pajak & 15,16 \\
\hline \multicolumn{3}{|c|}{ Jumlah Butir } & 16 \\
\hline
\end{tabular}




\begin{tabular}{|c|c|c|c|}
\hline No & Variabel & Faktor & No Butir \\
\hline \multirow[t]{4}{*}{2} & \multirow{4}{*}{$\begin{array}{l}\text { Tingkat Pemahaman } \\
\text { Wajib Pajak (X) } \\
\text { (Peraturan Daerah } \\
\text { Kabupaten Kota } \\
\text { Yogyakarta) }\end{array}$} & $\begin{array}{l}\text { Kepatuhan dalam } \\
\text { mendaftarkan diri ke kantor pajak }\end{array}$ & $1,2,3$ \\
\hline & & $\begin{array}{l}\text { Kepatuhan dalam melaporkan SPT tepat } \\
\text { waktu }\end{array}$ & $\begin{array}{l}4,5,6,7, \\
8\end{array}$ \\
\hline & & $\begin{array}{l}\text { Kepatuhan dalam menghitung } \\
\text { dan membayar } \\
\text { pajak dengan benar }\end{array}$ & $9,10,11$ \\
\hline & & $\begin{array}{l}\text { Kepatuhan dalam membayar tunggakan } \\
\text { pajak }\end{array}$ & $\begin{array}{l}12, \\
13, \\
14,15,16\end{array}$ \\
\hline \multicolumn{3}{|c|}{ Jumlah Butir } & 16 \\
\hline
\end{tabular}

\section{Pengujian Hipotesis Analisis Regresi Sederhana}

Analisis regresi adalah suatu analisis yang mengukur pengaruh antara variabel bebas terhadap variabel terikat. Jika pengukuran pengaruh ini melibatkan satu variabel bebas (X) dan variabel terikat (Y) dinamakan analisis regresi linear sederhana yang dirumuskan:

$$
\mathrm{Y}=\mathrm{a}+\mathrm{bX}
$$

Nilai a adalah konstanta dan nilai b adalah koefisien regresi untuk variabel $\mathrm{X}$. Dimana:

$\mathrm{Y}$ : subyek dalam variabel dependen yang diprediksikan

a : harga $Y$ ketika harga $X=0$ (harga konstan)

b : angka koefisien regresi

$\mathrm{X}$ : subyek pada variabel independen yang mempunyai nilai tertentu

\section{Uji Hipotesis (Uji t)}

Uji Statistik t pada dasarnya menunjukkan seberapa jauh pengaruh variabel penjelas atau independen secara individual dalam menerangkan variasi variabel dependen (Ghozali, 2013). Pengujian ini menggunakan tingkat signifikansi 5\% dan melakukan perbandingan antara $t_{\text {hitung }}$ dengan $t_{\text {tabel }}$. Menurut Sugiyono (2013) kriteria pengujian sebagai berikut:

a. Apabila signifikansi $<0,05$ maka $\mathrm{H}_{0}$ ditolak dan $\mathrm{H}_{\mathrm{a}}$ diterima, sehingga variabel bebas secara parsial memiliki pengaruh nyata terhadap variabel terikat.

b. Apabila signifikansi $>0,05$ maka $\mathrm{H}_{0}$ diterima dan $\mathrm{H}_{\mathrm{a}}$ ditolak, sehingga variabel bebas secara parsial tidak memiliki pengaruh nyata terhadap variabel terikat. 


\section{Dwi Priyanto, Eliya Isfaatun}

\section{Koefisien Determinasi (R2)}

Pada model regresi linier berganda, kontribusi variabel independen secara bersama-sama terhadap variabel dependen dapat diketahui dengan melihat besaran koefisien determinasi totalnya $(\mathrm{R})$. Jika nilai $(\mathrm{R})$ yang diperoleh mendekati 1, maka hubungan variabel independen terhadap variabel dependen semakin kuat. Sebaliknya jika nilai (R) yang diperoleh mendekati 0 maka hubungan variabel independen terhadap variabel dependen lemah. Nilai $(R)$ dapat naik atau turun apabila satu variabel independen ditambahkan ke dalam model.

\section{HASIL DAN PEMBAHASAN}

\section{Analisis Statistik Deskriptif Kepatuhan Wajib Pajak}

Berdasarkan hasil pengolahan, dapat dilihat bahwa rata-rata kepatuhan wajib pajak adalah 2,93. Rata-rata skor tersebut dimasukkan ke dalam garis kontinum yang dikategorikan ke dalam kriteria sangat baik, baik, cukup, kurang, dan sangat kurang berdasarkan skala likert pada gambar di bawah ini.

\section{Garis Kontinum Kepatuhan Wajib Pajak}

\begin{tabular}{|c|c|c|c|c|}
\hline $\begin{array}{c}\text { Sangat } \\
\text { Kurang }\end{array}$ & Kurang & Cukup & Baik & Sangat Baik \\
\hline $1,00-1,60$ & $1,61-2,20$ & $2,21-2,80$ & $2,81-3,40$ & $3,41-4,00$ \\
\hline
\end{tabular}

Berdasarkan hal di atas, menunjukkan bahwa rata-rata skor sebesar 2,93, dengan demikian, kepatuhan wajib pajak masuk dalam kategori baik.

\section{Analisis Statistik Deskriptif Tingkat Pemahaman Pajak Kos}

Berdasarkan hasil pengolahan bahwa rata-rata pemahaman tentang pajak kos adalah 3,02. Rata-rata skor tersebut dimasukkan ke dalam garis kontinum yang dikategorikan ke dalam kriteria sangat baik, baik, cukup, kurang, dan sangat kurang berdasarkan skala likert pada gambar di bawah ini.

Garis Kontinum Pemahaman tentang Pajak Kos

\begin{tabular}{|c|c|c|c|c|}
\hline $\begin{array}{c}\text { Sangat } \\
\text { Kurang }\end{array}$ & Kurang & Cukup & Baik & Sangat Baik \\
\hline $1,00-1,60$ & $1,61-2,20$ & $2,21-2,80$ & $2,81-3,40$ & $3,41-4,00$ \\
\hline
\end{tabular}


Berdasarkan hal di atas, menunjukkan bahwa rata-rata skor sebesar 3,02, dengan demikian, pemahaman tentang pajak kos masuk dalam kategori baik.

\section{Hasi Uji Asumsi Klasik}

Tujuan pengujian asumsi klasik ini adalah untuk memberikan kepastian bahwa persamaan regresi yang didapatkan memiliki ketepatan dalam estimasi, tidak bias dan konsisten. Uji asumsi klasik dalam penelitian ini dijelaskan sebagai berikut:

\section{Uji Normalitas}

Uji normalitas data dalam penelitian ini digunakan metode Kolmogorov Smirnov. Hasil uji normalitas data yang dilakukan pada tiap kelompok analisis dilakukan dengan program software SPSS version 23.0 for windows dengan taraf signifikansi 5\% atau 0,05 . Hasil selengkapnya disajikan pada lampiran halaman. Rangkuman data disajikan pada Tabel 2 sebagai berikut.

Tabel 2. Hasil Uji Normalitas

\begin{tabular}{|c|c|c|c|}
\hline Data & $\mathrm{p}$ & Signifikansi & Ket. \\
\hline $\begin{array}{c}\text { Tingkat Pemahaman } \\
\text { Pajak Kos }\end{array}$ & 0,325 & 0,05 & Normal \\
\hline Kepatuhan Wajib Pajak & 0,216 & & Normal \\
\hline
\end{tabular}

Sumber: data primer (2020)

Berdasarkan analisis statistik uji normalitas yang telah dilakukan dengan menggunakan uji Kolmogorov Smirnov, pada semua data didapat dari hasil uji normalitas data nilai signifikansi $p>0,05$, yang berarti data berdistribusi normal.

\section{Uji Linieritas}

Pengujian linieritas hubungan dilakukan melalui uji F. Hubungan antara variabel $\mathrm{X}$ dengan $\mathrm{Y}$ dinyatakan linier apabila nilai sig $>0,05$. Hasil uji linieritas dapat dilihat dalam tabel 4.12 berikut ini:

Tabel 3. Rangkuman Hasil Uji Linieritas

\begin{tabular}{cccc} 
Hubungan Fungsional & $\mathrm{p}$ & Sig. & Keteranga $\mathrm{n}$ \\
\hline $\mathrm{X} . \mathrm{Y}$ & $\begin{array}{c}0,40 \\
1\end{array}$ & 0,05 & Linier \\
\hline
\end{tabular}

Sumber: data primer (2020) 
Dari Tabel 3 di atas, terlihat bahwa nilai signifikansi $(p)$ adalah lebih besar dari 0,05 . Jadi, hubungan variabel bebas dengan variabel terikatnya dinyatakan linear.

\section{Hasil Uji Hipotesis}

Teknik analisis yang digunakan untuk menguji hipotesis menggunakan teknik analisis regresi linear sederhana, uji t, dan uji determinasi. Hasil uji hipotesis dipaparkan sebagai berikut:

\section{Regresi Linier Sederhana}

Analisis regresi linier sederhana bertujuan untuk mengetahui arah hubungan antara variabel independen dengan variabel dependen apakah variabel independen berhubungan positif atau negatif dan untuk memprediksi nilai dari variabel dependen apabila nilai variabel independen mengalami kenaikan atau penurunan. Hasil analisis pada Tabel 4 sebagai berikut:

\section{Tabel 4. Hasil Analisis Regresi Linier Sederhana}

\begin{tabular}{|l|c|c|c|c|c|}
\hline \multirow{2}{*}{ Model } & \multicolumn{2}{|c|}{$\begin{array}{c}\text { Unstandardized } \\
\text { Coefficients }\end{array}$} & $\begin{array}{c}\text { Standardized } \\
\text { Coefficients }\end{array}$ & \multirow{2}{*}{ t } & Sig. \\
\cline { 2 - 4 } & B & Std. Error & Beta & & \\
\hline 1 (Constant) & 14.516 & 2.059 & & 7.052 & .000 \\
\hline $\begin{array}{l}\text { Tingkat } \\
\text { Pemahaman } \\
\text { Pajak Kos }\end{array}$ & .671 & .042 & .707 & 15.920 & .000 \\
\hline
\end{tabular}

a. Dependent Variable: Kepatuhan Wajib Pajak Sumber: data primer (2020)

Dari hasil perhitungan pada Tabel 4 di atas, maka dapat dibuat persamaan regresi yaitu $Y=14,516+0,671 X$. Konstanta sebesar 14,516 artinya jika tingkat pemahaman pajak kos (X) nilainya adalah 0 , maka kepatuhan wajib pajak (Y) nilainya yaitu sebesar 14,516. Koefisien bernilai positif artinya terjadi hubungan positif antara tingkat pemahaman pajak kos terhadap kepatuhan wajib pajak.

\section{Uji Hipotesis (Uji t)}

Uji t dilakukan untuk mengetahui pengaruh variabel bebas $(\mathrm{X})$ terhadap variabel terikat (Y). Hasil analisis dijelaskan sebagai berikut:

\section{Menentukan rumusan hipotesis}

$\mathrm{H}_{0}$ : Tidak ada pengaruh yang positif dan signifikan tingkat pemahaman pajak kos terhadap kepatuhan wajib pajak

$\mathrm{H}_{\mathrm{a}}$ : $\quad$ Ada pengaruh yang positif dan signifikan tingkat pemahaman pajak kos terhadap kepatuhan wajib pajak 
1) Menentukan nilai $t_{\text {hitung }}$ dan $t_{\text {tabel }}$ dan nilai signifikansi

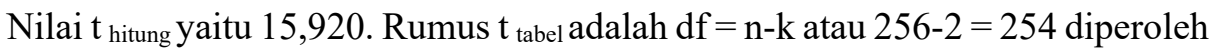
nilai $\mathrm{t}_{\text {tabel }} 1,650$ dan nilai signifikansi 0,000 .

2) Kriteria pengujian

a) Apabila signifikansi $<0,05$ maka $H_{o}$ ditolak dan $H_{a}$ diterima.

b) Apabila signifikansi $>0,05$ maka $H_{o}$ diterima dan $H_{a}$ ditolak.

3) Kesimpulan

Dapat dilihat bahwa $\mathrm{t}$ hitung 15,920 dan nilai signifikansi (sig) 0,000. Nilai $\mathrm{t}$ hitung 15,920 $>\mathrm{t}$ tabel 1,650 dan nilai signifikansi $0,000<0,05$, maka $\mathrm{H}_{0}$ ditolak dan $\mathrm{H}_{\mathrm{a}}$ diterima. Artinya ada pengaruh yang positif dan signifikan tingkat pemahaman pajak kos terhadap kepatuhan wajib pajak.

\section{Koefisien Determinasi (R2)}

Koefisien Determinasi (R2) pada intinya digunakan untuk mengukur seberapa jauh kemampuan model regresi dalam menerangkan variasi variabel dependen. Hasil analisis pada Tabel 4.14 sebagai berikut:

Tabel 5. Hasil Analisis Koefisien Determinasi (R)

\begin{tabular}{ccccc} 
Model & $\mathrm{R}$ & R Square & Adjusted R Square & $\begin{array}{c}\text { Std. Error of the } \\
\text { Estimate }\end{array}$ \\
\hline 1 & $.707^{\mathrm{a}}$ & .499 & .497 & 4.92135 \\
\hline
\end{tabular}

Predictors: (Constant), Tingkat Pemahaman Pajak Kos

(Sumber: Olah Data SPSS 23)

Dari Tabel 5 di atas diketahui bahwa besar koefisien korelasi adalah sebesar 0,707. Koefisien determinasi $R$ Square atau tingkat pemahaman pajak kos dalam menjelaskan atau memprediksi variabel kepatuhan wajib pajak sebesar 0,499 atau 49,9\%. Hal ini berarti variabel independen berpengaruh terhadap variabel dependen sebesar 49,9\%, sedangkan sisanya dipengaruhi faktor lain sebesar 50,1\% di luar penelitian ini.

\section{Pembahasan}

Berdasarkan beberapa hasil penelitian di atas, menunjukkan bahwa ada pengaruh yang positif dan signifikan tingkat pemahaman pajak kos terhadap kepatuhan wajib pajak. Hal ini dibuktikan melalui uji $\mathrm{t}$ dengan hasil $\mathrm{t}$ hitung 15,920 $>\mathrm{t}$ tabel 1,650 dan persamaan regresi yaitu $\mathrm{Y}=14,516+0,671 \mathrm{X}$. Dari hasil tersebut diartikan bahwa semakin tinggi/baik tingkat pemahaman pajak kos, maka kepatuhan wajib pajak semakin meningkat. 


\section{Dwi Priyanto, Eliya Isfaatun}

Tiraada (2013) menyatakan bahwa kepatuhan wajib pajak merupakan pemenuhan kewajiban perpajakan yang dilakukan oleh pembayar pajak dalam rangka memberikan kontribusi bagi pembangunan negara dan dalam pemenuhan kewajibannya dilakukan secara sukarela. Kepatuhan wajib pajak menjadi aspek penting mengingat sistem perpajakan Indonesia menganut system selfassessment, yang memberikan kepercayaan kepada wajib pajak untuk menghitung, membayar, dan melaporkan kewajibannya.

Setiap Wajib Pajak yang terdaftar tentu memiliki Nomor Pokok Wajib Pajak (NPWP), dianggap sudah mengerti dan memahami mengenai peraturan perpajakan yang berlaku. Namun, menurut Ortax.org, (Agustiningsih, 2016) dalam prakteknya masih banyak Wajib Pajak yang kurang paham tentang peraturan perpajakan bahkan masih ada Wajib Pajak yang tidak tahu sama sekali mengenai peraturan perpajakan yang berlaku. Masih ada beberapa Wajib Pajak yang tidak sepenuhnya memahami tentang peraturan perpajakan akan berdampak pada penerimaan pajak di Indonesia. Seorang Wajib Pajak dapat dikatakan patuh dalam kegiatan perpajakan apabila memahami secara penuh tentang peraturan perpajakan antara lain: mengetahui dan berusaha memahami Undang-Undang Perpajakan, cara pengisian formulir perpajakan, cara menghitung pajak, cara melaporkan SPT dan selalu membayar pajak tepat waktu. Kurangnya kesadaran masyarakat di Dusun Umbulharjo ini, karena banyaknya pendiri kos yang belum memiliki NPWP, sehingga tidak merasa mempunyai kewajiban dalam perpajakan.

Penelitian ini sejalan dengan penelitian yang dilakukan oleh Dian Widiastuti (2014) yang menunjukan pemahaman memiliki pengaruh positif terhadap kepatuhan wajib pajak. Hasil dari penelitian ini mendukung penelitian yang dilakukan oleh Hardiningsih dan Yulianawati, (2011: 130) yang menyatakan pemahaman wajib pajak akan peraturan perpajakan merupakan cara wajib pajak dalam memahami peraturan perpajakan yang telah ada. Wajib pajak yang tidak memahami peraturan perpajakan secara jelas cenderung akan menjadi wajib pajak yang tidak patuh, maka semakin tinggi pemahaman wajib pajak akan peraturan pajak perpajakan dan pemahaman akan sistem pemunggutan pajaknya semakin pula wajib pajak paham akan sanksi perpajakan. Kesimpulannya, bahwa pemahaman wajib pajak berpengaruh signifikan terhadap Kepatuhan Wajib Pajak.

Kepatuhan Wajib Pajak merupakan kesadaran untuk tunduk terhadap peraturan perpajakan yang berlaku dan sekaligus juga dalam prosedur administrasi perpajakan. Dalam faktor ketaatan atau kepatuhan perilaku wajib pajak cenderung untuk melakukan kegiatan menghindar dari kewajibannya menurut Simanjuntak dan Mukhlis (2012: 85). Kesadaran dan kepatuhan masyarakat untuk memenuhi kewajiban perpajakan sesuai

dengan peraturan yang berlaku perlu ditumbuhkan secara terus-menerus, hal ini adalah salah satu upaya untuk meningkatkan target pajak yang terealisasi.

Pemahaman wajib pajak akan peraturan perpajakan merupakan cara wajib pajak dalam memahami peraturan perpajakan yang telah ada. Wajib pajak yang tidak memahami peraturan perpajakan secara jelas cenderung akan menjadi wajib pajak yang tidak patuh, maka semakin paham wajib pajak akan peraturan perpajakan semakin pula 
wajib pajak paham akan sanksi perpajakan bila melalaikan kewajiban perpajakan mereka. Wajib pajak yang benar-benar paham akan peraturan perpajakan, wajib pajak akan tahu adanya sanksi administrasi maupun sanksi pidana (Hardiningsih dan Yulianawati, 2011:130).

Agar pemungutan pajak rumah kos di pungut secara efektif, maka pemahaman masyarakat, petugas pajak harus sesuai dengan ketentuan yang diatur dalam UU serta peraturan daerah yang mengatur tentang pajak daerah. Hal ini memerlukan sosialisasi kepada masyarakat umum sehingga mereka mau dengan sadar membayarnya. Susanto (2012), menyatakan bahwa upaya untuk meningkatkan kesadaran dan kepatuhan wajib pajak dilakukan dengan sosialisasi perpajakan dengan beragam bentuk cara dan sosialisasi. Namun kegiatan sosialisasi harus dilakukan secara efektif dan dilakukan dengan media-media yang mudah diketahui oleh masyarakat. Sebelum berlakunya pemungutan pajak hotel atas rumah kos ini sudah dilakukanya sosialisasi selama kurang lebih tiga tahun terkakhir namun Dinas Pendapatan Daerah Kota Malang masih saja menemukan wajib pajak hotel atas rumah kos yang menghindar dalam membayar pajak atas rumah kos ini.

Hasil analisis deskriptif menunjukkan bahwa rata-rata skor kepatuhan wajib pajak sebesar 2,93, masuk dalam kategori baik, dan rata-rata skor pemahaman tentang pajak kos sebesar 3,02, masuk dalam kategori baik. Hasil tersebut berbeda dengan hasil survei di Kecamatan Umbulharjo tercatat hanya 12 wajib pajak dari 710 orang yang patuh melaporkan pajak kos. Hal tersebut dikarenakan pengumpulan data dalam penelitian ini hanya didasarkan pada hasil kuesioner, sehingga dimungkinkan adanya unsur kurang objektif dalam pengisian kuesioner. Selain itu dalam pengisian kuesioner diperoleh adanya sifat responden sendiri seperti kejujuran dan ketakutan dalam menjawab responden tersebut dengan sebenarnya.Untuk memaksimalkan pendapatan daerah dari pajak kos disarankan agar petugas pemungut pajak memberi pengertian tentang pajak dan memungut pajak dari rumah ke rumah agar lebih efektif.Perlu adanya pembaharuan Peraturan Daerah tentang pajak kos karena perkembangan pengetahuan dan situasi kondisi masarakat yang semakin maju diikuti juga dengan kebutuhan aturan untuk menyelesaikan atau mengantisipasi masalah.

\section{KESIMPULAN DAN SARAN KESIMPULAN}

Berdasarkan hasil analisis data dan pembahasan dapat diambil kesimpulan, bahwa ada pengaruh yang positif dan signifikan tingkat pemahaman pajak kos terhadap kepatuhan wajib pajak. Hal ini dibuktikan melalui uji $t$ dengan hasil $t_{\text {hitung }} 15,920>t_{\text {tabel }}$ 1,650 dan persamaan regresi yaitu $Y=14,516+0,671 X$. Dari hasil tersebut diartikan bahwa semakin tinggi/baik tingkat pemahaman pajak kos, maka kepatuhan wajib pajak semakin meningkat. Hal ini juga didukung dengan nilai signifikansi yaitu 0,000, yang berarti bahwa nilai signifikansi tersebut lebih kecil dari 0,05 . 


\section{Dwi Priyanto, Eliya Isfaatun}

\section{DAFTAR PUSTAKA}

Agustiningsih, D. (2016). Pengaruh penerapan e-filing, tingkat pemahaman perpajakan dan kesadaran wajib pajak terhadap kepatuhan wajib pajak di KPP Pratama Yogyakarta. Jurnal Nominal / Volume V Nomor 2.

Direktorat Jenderal Pajak. 2011. Surat Edaran Direktur Jenderal Pajak, Nomor SE- 98/ PJ/2011.Direktorat Jenderal Pajak.

Ghozali, I. (2013). Aplikasi analisis multivariate dengan program SPSS. Edisi Ketujuh. Semarang: Badan Penerbit Universitas Diponegoro.

Hardiningsih, P dan Yulianawati, N. (2011). Faktor-faktor yang mempengaruhi kemauan membayar pajak. Dinamika Keuangan dan Perbankan, Vol.3 No. 1.

Muliari, Ni Ketut \& Setiawan, P.E. (2011). Pengaruh persepsi tentang sanksi perpajakan dan kesadaran wajib pajak pada kepatuhan pelaporan wajib pajak orang pribadi di kantor pelayanan pajak pratama Denpasar Timur. Jurnal Ilmiah Akuntansi dan Bisnis, 6 (1): pp. 1-23.

Nugroho \& Zulaikha (2012). Faktor-faktor yang memepengaruhi kemauan untuk membayar pajak dengan kesadaran membayar pajak sebagai variabel intervening. Jurnal Diponegoro, Vol.1, No.2, h. 1-11.

Peraturan Menteri Keuangan Republik Indonesia No.74/PMK.03/2012 Pasal 2 tentang Pengembalian Pendahuluan Kelebihan Pembayaran Pajak bagi wajib pajak patuh.

Prawagis. D. (2016). Pengaruh pemahaman atas mekanisme pembayaran pajak, persepsi tarif pajak dan sanksi pajak terhadap kepatuhan wajib pajak UMKM. Jurnal Perpajakan (JEJAK), Vol. 10 No. 2.

Purwanto, N. (2013). Evaluasi hasil belajar. Yogyakarta: Pustaka Pelajar.

Rahayu, S.K. (2010). Perpajakan Indonesia-konsep dan aspek formal. Jakarta: Graha Ilmu.

Simanjuntak, T.H \& Mukhlis, I. (2012). Dimensi ekonomi perpajakan dalam pembangunan ekonomi. Jakarta: Raih Asa Sukses.

Slamet, E \& S. Jurdi. (2015). Politik perpajakan, membangun demokrasi negara. Jakarta: UI Press.

Sugiyono. (2013). Metode penelitian kuantitatif, kualitatif, dan R\&D. Bandung: Alfabeta.

Susanto, H. (2012). Membangun kesadaran dan kepedulian sukarela wajib pajak. http://pajak.go.id (diakses pada tanggal 1 Maret 2020).

Waluyo. (2011). Perpajakan Indonesia. Jakarta: Penerbit Salemba Empat. 
Wandayu \& Pusposari (2016). Persepsi pemilik usaha kos terhadap pemungutan pajak penghasilan pasal 4 ayat 2 atas penghasilan dari persewaan tanah dan/ bangunan kategori rumah indekos di Kota Malang. Jurnal Ilmiah Mahasiswa FEB UNIBRAW, Volume 4 No 1.

Wirawan, B.I \& Burton, R. (2013). Hukum pajak, edisi 6. Jakarta: Salemba Empat. 
